\title{
Perbandingan Pendapatan Peternak Ayam dan Industri Rumah Tangga (Industri Purun) terhadap Permodalan PUAP Di Desa Panyaungan Kecamatan Amuntai Utara Kabupaten Hulu Sungai Utara
}

\section{(Comparison of Household and Industrial Household (Purun Industry) Income on PUAP Capital in Panyaungan Village Amuntai Utara District Hulu Sungai Utara Regency)}

\author{
Rachman Fitriannor $^{1)}$ \& Muzalifah ${ }^{2)}$ \\ Program Studi Agribisnis, Sekolah Tinggi Ilmu Pertanian Amuntai \\ ${ }^{1)}$ rafi@yahoo.com \\ ${ }^{2)}$ muzalifah@yahoo.com
}

\begin{abstract}
ABSTRAK
Penelitian ini bertujuan mengetahui (i) total pendapatan yang diperoleh responden yang mengusahakan ternak ayam broiler (ii) total pendapatan yang diperoleh responden yang mengusahakanindustri rumah tangga anyaman purun, (iii) besarnya perbedaan total pendapatan yang diperoleh responden yang mengusahakan ternak ayam broiler, dengan yang mengusahakan industri tumah tangga anyaman purun. Hasil penelitian menunjukkan bahwa: biaya total untuk usaha ternak ayam broiler yang dilaksanakan responden Di Desa Panyaungan Kecamatan Amuntai Utara Kabupaten Hulu Sungai Utara, rata-rata Rp.21.004.932,10. Dengan rincian biaya rata-rata biaya tetap sebesar Rp.577.744, 60 / periode pemeliharaan dan rata-rata biaya variabel mencapai Rp.20.427.187.50 / periode pemeliharaan. Penerimaan rata-rata Rp.23.307.375,00 / peroide pemeliharaan, dengan keuntungan rata-rata mencapai Rp.2.302.443,00/ periode pemeliharaan. Sedangkan responden yang mengusahakan anyaman tikar purun, jumlah biaya total yang dikeluarkan rata-rata mencapai Rp2.053.134,70. Rata-rata biaya tetap yang dikeluarkan mencapai Rp.828.010,00 / bulan, dan rata-rata biaya variabel yang dikeluarkan mencapai Rp.1.225.125,00 / bulan. Penerimaan rata-rata mencapai Rp.2.250.000,00 / bulan, dan keuntungan ratarata yang diperoleh mencapai Rp.196.685,00 / bulan. Usaha ternak ayam broiler dan anyaman tikar purun layak untuk diusahakan, karena nilai RCR dari kedua jenis usaha tersebut > dari 1. Nilai RCR pada usaha ternak ayam broiler mencapai 1.107 dan nilai RCR pada usaha anyaman purun mencapai 1.096. Dengan demikian usahatani yang diselenggarakan layak untuk diusahakan, karena setiap korbanan sebesar Rp.1.00 akan menghasilkan Rp.1.107 dan Rp.1.096.
\end{abstract}

Kata kunci: Usaha, ternak, ayam, broiler, anyaman.

\begin{abstract}
This study aims to find out (i) the total income obtained by respondents seeking broiler chicken livestock (ii) the total income obtained by respondents seeking purun woven industry, (iii) the amount of difference in total income obtained by respondents seeking broiler chickens, with those strive for purun plaited household industry. The results showed that: total costs for broiler chicken farming conducted by respondents in Panyaungan Village, North Amuntai Sub-District, Hulu Sungai Utara Regency, averaged Rp.21,004,932.10. With details of the average cost of fixed costs of Rp.577,744, 60 / period of maintenance and the average variable costs reached Rp.20,427,187.50 / maintenance period. Average revenue of Rp. 23,307,375.00 / peroide of maintenance, with an average profit reaching Rp.2,302,443.00 / maintenance period. While respondents who sought purun matting, the total cost incurred averaged Rp2,053,134.70. Average fixed costs incurred reached Rp.828,010.00 / month, and the average variable costs incurred reached Rp.1,225,125.00 / month. The average income reaches $R p .2,250,000.00 /$ month, and the average profit obtained reaches Rp.196,685.00 / month. Broiler chicken and purun matting are feasible, because the RCR value of the two types of business is $>1$. The RCR value of broiler chicken farming reaches 1,107 and the RCR value of purun plait business reaches 1,096. Thus the farming that is held is feasible to be cultivated, because every sacrifice of Rp. 1.00 will produce Rp. 1,107 and Rp. 1,096.
\end{abstract}

Keywords : Business, livestock, chicken, broiler, wicker. 
PUAP merupakan bentuk fasilitasi bantuan modal usaha untuk petani anggota, baik petani pemilik, petani penggarap, buruh tani maupun rumah tangga tani yang dikoordinasikan oleh Gabungan Kelompok Tani (Gapoktan). Gabungan Kelompok Tani (Gapoktan) merupakan kelembagaan tani pelaksana PUAP untuk penyaluran bantuan modal usaha bagi anggota. Untuk mencapai hasil yang maksimal dalam pelaksanaan PUAP, Gapoktan didampingi oleh tenaga Penyuluh Pendamping dan Penyelia Mitra Tani (PMT).

PUAP bertujuan untuk (a) mengurangi kemiskinan dan pengangguran melalui penumbuhan dan pengembangan kegiatan usaha agribisnis di perdesaan sesuai dengan potensi wilayah, (b) meningkatkan kemampuan pelaku usaha agribisnis, Pengurus Gapoktan, Penyuluh dan Penyelia Mitra Tani, (c) memberdayakan kelembagaan petani dan ekonomi perdesaan untuk pengembangan kegiatan usaha agribisnis, dan (d) meningkatkan fungsi kelembagaan ekonomi petani menjadi jejaring atau mitra lembaga keuangan dalam rangka akses ke permodalan (Anonim, 2008).

Tabel 1. Daftar desa yang mendapatkan alokasi dana PUAP di Kecamatan Amuntai Utara 20082012.

\begin{tabular}{clcccccc}
\hline \multirow{2}{*}{ No Desa } & & \multicolumn{5}{c}{ Tahun } & Total (bh) \\
\cline { 3 - 7 } & & 2008 & 2009 & 2010 & 2011 & 2012 & 1 \\
2 & Pandawanan & 1 & - & - & - & - & 1 \\
3 & Puntung & 1 & - & - & - & - & 1 \\
4 & Padang Basar Hilir & - & 1 & - & - & - & 1 \\
5 & Cakru & - & - & 1 & - & - & 1 \\
6 & Kamayahan & - & - & - & 1 & - & 1 \\
7 & Padang Basar Hulu & - & - & - & 1 & - & 1 \\
8 & Panyaungan & - & - & - & 1 & - & 1 \\
9 & Sungai Turak Dalam & - & - & - & 1 & - & 1 \\
10 & Tabalong Mati & - & - & - & 1 & - & 1 \\
11 & Telaga Bamban & - & - & - & 1 & - & 1 \\
12 & Air Tawar & - & - & - & 1 & - & 1 \\
\hline$\quad$ Total: & - & - & - & - & 1 & 1 \\
\hline
\end{tabular}

Sumber: BP4KKP Kabupaten Hulu Sungai Utara (2012).

Tabel 3 menunjukkan bahwa dari 2008-2012, alokasi bantuan dana PUAP di Kecamatan Amuntai Utara terbanyak adalah tahun 2011, yaitu 7 Gapoktan. Selanjutnya pada tahun 2009, 2010 dan 2012 hanya 1 Gapoktan yang mendapatkan bantuan dana PUAP. Desa Panyaungan Kecamatan
Keberhasilan PUAP tidak terlepas dari partisipasi petani yang dikoordinasikan dalam Gapoktan. Dalam PUAP ada tiga faktor yang mendapat perhatian: (1) Pengetahuan tentang pengertian, tujuan dan manfaat dari suatu inovasi teknologi. (2) Sikap untuk menyadari dan mau mengadopsi inovasi (3) Kelompok tani sebagai unit produksi, wadah kerjasama dan kelas belajar antara anggota dan pengurus kelompoktani (Anonim, 2008).

Provinsi Kalimantan Selatan sejak 2008-2012 telah menerima alokasi bantuan dana PUAP sebanyak 1.367 Gapoktan, yang tersebar ke 13 wilayah di Kabupaten. Dana PUAP yang dikucurkan kepada anggota Gapoktan tersebut, diharapkan bisa membantu memperbaiki kualitas kehidupan petani dan keluarganya. Pelaksanaannya dapat melalui usaha yang bersifat on farm seperti usaha dalam bidang tanaman pangan, peternakan dan perkebunan, maupun off farm seperti industri rumah tangga, bebakulan dan pengolahan hasil pertanian. 
sebagaian mengusahakan ternak ayam ras broiler. Disamping itu masyarakatnya berusaha dalam bidang industri rumah tangga, seperti anyaman lampit, dan anyaman purun.

Gapoktan Tani Membangun dari desa Panyaungan Kecamatan Amuntai Utara, adalah merupakan gabungan dari beberapa kelompok tani yang ada di desa tersebut. Alokasi bantuan dana yang diterima oleh anggotanya dimanfaatkan untuk usaha ternak ayam broiler dan sebagian untuk usaha industri rumah tangga anyaman purun.

Potensi usaha ternak unggas khususnya ayam broiler dan industri rumah tangga anyaman purun, merupakan usaha yang telah lama digeluti oleh masyarakat di
Desa Panyaungan. Disamping itu masyarakatnya juga berusahatani padi, palawija dan mengusahakan ternak unggas yang lain.

Usaha ternak ayam broiler dan usaha industri rumah tangga anyaman purun di desa penelitian, memiliki peluang usaha yang cukup baik. Potensi untuk pengembangan ternak unggas tersedia. Begitu juga dengan industri anyaman purun, disamping bahan bakunya tersedia dalam jumlah yang banyak, ketersediaan tenaga kerja serta sumberdaya manusianya cukup trampil.

Perkembangan usaha peternakan di Kabupaten Hulu Sungai Utara, khususnya ternak unggas disajikan pada Tabel 2, berikut.

Tabel 2. Usaha peternakan unggas di Kabupaten Hulu Sungai Utara Tahun 2012.

\begin{tabular}{llccc}
\hline No. & Kecamatan & $\begin{array}{c}\text { Ayam Pedaging } \\
\text { (ekor) }\end{array}$ & Ayam Buras (ekor) & Itik (ekor) \\
\hline 1 & Danau Panggang & 12.785 & 36.975 & 3.052 \\
2 & Paminggir & - & 2.728 & 91 \\
3 & Babirik & 2.400 & 29.104 & 3.008 \\
4 & Sungai Pandan & 48.710 & 19.243 & 3.095 \\
5 & Sungai Tabukan & 37.020 & 4.086 & 1.925 \\
6 & Amuntai Selatan & 100.922 & 33.592 & 3.575 \\
7 & Amuntai Tengah & 46.300 & 10.439 & 3.176 \\
8 & Banjang & 29.800 & 1.365 & 750 \\
9 & Amuntai Utara & 36.579 & 2.275 & 22.336 \\
10 & Haur Gading & 18.380 & 6.809 & 701 \\
\hline
\end{tabular}

Sumber: Dinas Perikanan dan Peternakan Kabupaten Hulu Sungai Utara (2012).

Tabel 2 menunjukkan bahwa pada tahun 2012 ternak ayam broiler merupakan ternak unggulan di Kabupaten Hulu Sungai Utara, populasinya mencapai 332.896 ekor. Usaha peternakan ayam broiler tarbanyak di Kecamatan Amuntai Selatan, yaitu 100.922 ekor. Sedangkan Kecamatan Amuntai Utara tempat penelitian ini berlangsung menempati urutan ke tujuh, yaitu 36.579 ekor.

Berikut perkembangan ternak unggas ayam broiler yang diusahakan oleh Gapoktan penerima dana PUAP di desa Panyaungan dari 2008-2012.

Tabel 3. Perkembangan usaha ternak ayam pedaging yang dikelola Gapoktan penerima dana PUAP di Desa Panyaungan Kecamatan Amuntai Utara dari 2008-2012

\begin{tabular}{llccccc}
\hline \multirow{2}{*}{ No. } & \multirow{2}{*}{ Jenis Ternak } & \multicolumn{5}{c}{ Tahun (ekor) } \\
\cline { 3 - 6 } & Ayam Pedaging & 2008 & 2009 & 2010 & 2011 & 2012 \\
\hline 1 & 1030 & 1960 & 3148 & 6279 & 8350 \\
2 & Ayam Buras & 66 & 109 & 126 & 149 & 163 \\
3 & Itik & 189 & 196 & 218 & 263 & 377 \\
\hline
\end{tabular}

Sumber: Dinas Perikanan dan Peternakan Kabupaten Hulu Sungai Utara (2012).

Selama lima tahun dari 2008-2012, usaha ternak unggas jenis ayam broiler di desa penelitian adalah merupakan usaha ternak yang terbanyak dibanding ternak unggas yang 
lain, yaitu mencapai 8350 ekor pada 2012, sementara ternak ayam buras hanya 163 ekor, dan ternak itik hanya 377 ekor.

Sebagaimana dikemukakan di atas bahwasanya selain berusahatani padi, palawija, sayuran dan beternak unggas, masyarakat tani di desa Panyaungan juga berusaha dalam bidang industri rumah tangga berupa anyaman purun. Anyaman purun oleh penduduk di desa tersebut merupakan usaha rumah tangga turun-temurun yang diwariskan oleh nenek moyang mereka. Usaha anyaman purun ini kebanyakan dikerjakan oleh kaum ibu selepas dari pekerjaan bertani. Berbagai produk yang dihasilkan dari industri purun ini berupa anyaman seperti kampil, tikar, sajadah, tas, dompet dan masih banyak lagi produk lain yang sangat menarik dan dipasarkan sebagai cindera mata atau keperluan sehari-hari.

Industri rumah tangga anyaman purun di desa Panyaungan, bahan bakunya cukup banyak tersedia, selain itu juga didukung suberdaya manusianya yang cukup trampil dalam membuat kerajinan dari bahan dasar purun tersebut. Yang menjadi permasalahan dari sebagian pengusaha industri rumah tangga ini adalah permodalan.

Keberadaan program PUAP di desa Panyaungan Kecamatan Amuntai Utara, diharapkan dapat memberikan motivasi kepada pengrajin purun yang tergabung dalam anggota Gapoktan Tani Membangun, agar bisa meningkatkan usahanya dengan skala usaha yang lebih besar dan kualitas yang lebih baik.

Industri kerajinan anyaman purun merupakan salah satu dari usaha di bidang agribisnis sekaligus merupakan produk kebanggaan masyarakat di Kecamatan Amuntai Utara khususnya di desa Panyaungan. Industri rumah tangga anyaman purun di Kecamatan Amuntai Utara disajikan pada Tabel 4, berikut.

Tabel 4. Perkembangan industri rumah tangga anyaman purun di Kecamatan Amuntai Utara Tahun dari 2008-2012.

\begin{tabular}{clccccc}
\hline \multirow{2}{*}{ No. Desa } & & \multicolumn{5}{c}{ Tahun (KK) } \\
\cline { 3 - 6 } 1 & Pandawanan & 2008 & 2009 & 2010 & 2011 & 2012 \\
2 & Guntung & - & 119 & 145 & 160 & 168 \\
3 & Pimping & - & - & - & - & - \\
4 & Padang Basar Hilir & - & - & - & - & - \\
5 & Cakru & - & - & - & - & - \\
6 & Kamayahan & 144 & 156 & 173 & - & - \\
7 & Padang Basar Hulu & - & - & - & - & 214 \\
8 & Panyaungan & 63 & 78 & 86 & 93 & - \\
9 & Sungai Turak Dalam & - & - & - & - & - \\
10 & Tabalong Mati & 64 & 64 & 103 & 146 & 256 \\
11 & Telaga Bamban & 78 & 96 & 114 & 136 & 216 \\
12 & Air Tawar & - & - & - & - & - \\
13 & Panangkalaan Hulu & - & - & - & - & - \\
14 & Sungai Turak & - & - & - & 2 & 2 \\
15 & Pamintangan & - & - & - & - & - \\
16 & Pakapuran & - & - & - & - & - \\
17 & Pakacangan & - & - & - & - & - \\
18 & Panangkalaan & - & - & - & - & - \\
19 & Kuangan & - & - & - & - & - \\
20 & Teluk Daun & - & - & - & - & - \\
21 & Muara Baruh & - & - & - & - & - \\
22 & Tayur & - & - & - & - & - \\
23 & Tebing Liring & - & - & - & - & - \\
24 & Padang Luar & 101 & 122 & 143 & 150 & 171 \\
25 & Murung Karangan & - & - & - & - \\
26 & Panangian & - & - & - & - \\
\hline & & 569 & 649 & 764 & 887 & 1.042 \\
\hline
\end{tabular}

Sumber: Dinas Perindustrian dan Perdagangan Kabupaten Hulu Sungai Utara Tahun (2012). 
Tabel 4 di atas menunjukkan bahwa industri rumah tangga anyaman purun di wilayah Kecamatan Amuntai Utara sampai dengan 2012, terbanyak adalah di desa Tabalong Mati, 256 kepala keluarga, dan paling sedikit jumlahnya adalah di desa Panyaungan, 115 kepala keluarga. Penelitian ini bertujuan untuk (i) mengetahui total pendapatan yang diperoleh

responden yang mengusahakan ternak ayam broile, (ii) mengetahui total pendapatan yang diperoleh responden yang mengusahakan industri rumah tangga anyaman purun, dan (iii) mengetahui besarnya perbedaan total pendapatan yang diperoleh responden yang mengusahakan ternak ayam ras pedaging, dengan yang mengusahakan industri rumah tangga anyaman purun.

\section{METODE PENELITIAN}

\section{Tempat dan Waktu}

Penelitian ini dilakukan di Desa Panyaungan Kecamatan Amuntai Utara Kabupaten Hulu Sungai Utara. Dilaksanakan sejak bulan April - Juli 2013, mulai dari persiapan, pengumpulan data, pemngolahan data sampai dengan penyusunan laporan.

\section{Jenis dan Sumber Data}

Data yang dikumpulkan berupa data primer dan data sekunder. Data primer diperoleh dari hasil wawancara dengan responden dari kedua jenis usaha, yakni responden yang mengusahakan ternak ayam ras pedaging (broiler) dan responden yang berusaha dalam bidang industri rumah tangga anyaman purun. Sedangkan data sekunder diperoleh dari hasil survey dan dari dinas/instansi terkait di Kabupaten Hulu Sungai Utara.

\section{Analisa Data}

Untuk menjawab tujuan pertama, kedua dan ketiga dari responden peserta PUAP dari Gapoktan Tani Membangun Desa Panyaungan Kecamatan Amuntai Utara Kabupaten Hulu Sungai Utara; yang melaksanakan usaha ternak ayam ras pedaging (broiler) dan yang mengusahakan industri rumah tangga anyaman purun, menggunakan persamaan sebagai berikut:
Untuk menghitung biaya yang dikeluarkan dalam satu usaha dilakukan dengan menggunakan pendekatan persamaan yang dikemukakan oleh Boediono (1989) sebagai berikut:

$$
\mathrm{TC}=\mathrm{TFC}+\mathrm{TVC}
$$

Keterangan:

$\mathrm{TC}=$ Total Coast/total biaya

( $\mathrm{Rp} / \mathrm{kg} /$ periode $)$

TFC = Total Fixed Coast/total biaya tetap $(\mathrm{Rp} / \mathrm{kg} /$ periode $)$

TVC = Total Variable Coast/total biaya variabel $(\mathrm{Rp} / \mathrm{kg} /$ periode)

Rumus penerimaan (revenue)

menurut Wasis (1981) ditentukan dengan pendekatan persamaan:

$$
\mathrm{TR}=\mathrm{P} \times \mathrm{Q}
$$

Keterangan:

$\mathrm{TR}=$ Total Revenue/total penerimaan

$(\mathrm{Rp} / \mathrm{kg} /$ periode $)$

$\mathrm{P} \quad=$ Price $/$ harga $(\mathrm{Rp} / \mathrm{kg})$

$\mathrm{Q}=$ Quantity/jumlah produksi

(kg/periode)

Menurut Arsyad (2000), besarnya

keuntungan (laba) diperoleh dari:

$$
\Pi=\mathrm{TR}-\mathrm{TC}
$$

Keterangan:

$\Pi=$ Profit/laba/keuntungan

$(\mathrm{Rp} / \mathrm{kg} /$ periode $)$

$\mathrm{TR}=$ Total Revenue/total penerimaan

( $\mathrm{Rp} / \mathrm{kg} /$ periode)

$\mathrm{TC}=$ Total Coast/total biaya

( $\mathrm{Rp} / \mathrm{kg} /$ periode)

Analisis perbandingan dilakukan dengan membandingkan biaya, penerimaan dan keuntungan antara kedua jenis usaha ternak ayam ras pedaging (broiler) dengan usaha industri rumah tangga anyaman purun (Arsyad, 2000).

$$
\Pi=\frac{\mathrm{TR}(\mathrm{tab})-\mathrm{TR}(\mathrm{Ap})}{\mathrm{TR}(\mathrm{tab})} \times 100 \%
$$

Keterangan:

$\mathrm{TR}(\mathrm{tab})=$ penerimaan usaha ternak ayam broiler $(\mathrm{Rp} / \mathrm{kg} /$ periode $)$

$\mathrm{TR}(\mathrm{Ap})=$ penerimaan usaha industry rumah tangga anyaman purun (Rp/kg/bulan) 


\section{HASIL DAN PEMBAHASAN}

Umur

\section{Keadaan Petani Responden}

Umur petani cukup berpengaruh dalam hal keberhasilan usahatani seseorang.
Rata-rata umur petani sampel pada usaha pemeliharaan ayam broiler (ayam ras pedaging) dan responden yang tergabung dalam usaha anyaman tikar purun di desa Panyaungan Kecamatan Amuntai Utara dapat dilihat pada Tabel 5.

Tabel 5. Jumlah petani responden berdasarkan kelompok umur di Desa Panyaungan Kecamatan Amuntgai Utara

\begin{tabular}{cccc}
\hline No. & Kelompok Umur (Tahun) & Jumlah (Jiwa) & Persentase (\%) \\
\hline 1. & $20-29$ & 5 & 12,5 \\
2. & $30-39$ & 14 & 35,0 \\
3. & $40-49$ & 13 & 32,5 \\
4. & $50-59$ & 8 & 20,0 \\
\hline & & 40 & 100 \\
\hline
\end{tabular}

Dari hasil penelitian diketahui umur petani responden berkisar antara 20 sampai dengan 59 tahun. Kelompok umur 30-39 tahun merupakan kelompok umur terbanyak yaitu 14 orang atau sebesar $35,0 \%$ dari seluruh jumlah petani responden, sedangkan kelompok umur 20-29 tahun merupakan kelompok umur terkecil yaitu 5 orang atau sebanyak $12,5 \%$ dari seluruh jumlah petani responden.

\section{Pendidikan}

Pendidikan merupakan salah satu faktor penting bagi petani dalam menentukan pengambilan keputusan serta adopsi inovasi dalam kegiatan usahatani. Jumlah petani responden pada penelitian ini dapat dilihat pada Tabel 6.

Tabel 6. Jumlah petani responden berdasarkan tingkat pendidikan di Desa Panyaungan Kecamatan Amuntai Utara

\begin{tabular}{|c|c|c|c|}
\hline No. & Kelompok Umur (Tahun) & Jumlah (Jiwa) & Persentase $(\%)$ \\
\hline 1. & Tidak tamat SD & - & - \\
\hline 2. & Tamat SD/sederajat & 18 & 45,0 \\
\hline 3. & Tamat SLTP/sederajat & 8 & 20,0 \\
\hline \multirow[t]{2}{*}{4.} & Tamat SLTA/sederajat & 14 & 35,0 \\
\hline & Jumlah: & 40 & 100 \\
\hline
\end{tabular}

Tingkat pendidikan petani responden terbanyak, yang ada di Desa Panyaungan Kecamatan Amuntai Utara yang mengusahakan ternak ayam broiler dan yang berusaha membuat anyaman tikar purun saat penelitian ini berlangsung, adalah responden yang tamat SD/sederajat, yakni sebanyak 18 orang atau $45 \%$ dari seluruh petani sampel. Sedangkan tingkat pendidikan responden terkecil adalah petani yang tidak tamat SLTP/sederajat yaitu 8 orang atau $20,0 \%$. Sedangkan responden yang tidak tamat SD tidak ada.

\section{Tanggungan Keluarga}

Tanggungan keluarga yang dimaksud adalah anggota keluarga yang ditanggung oleh kepala keluarga yang terdiri dari isteri, anak dan seluruh anggota keluarga yang lain atau orang lain yang tinggal dalam satu rumah yang menjadi tanggungan kepala keluarga untuk menghidupinya. Jumlah tanggungan keluarga dari responden yang pada penelitian ini dapat dilihat pada Tabel 7 . 
Tabel 7. Jumlah tanggungan keluarga dari petani responden di Desa Panyaungan Kecamatan Amuntai Utara

\begin{tabular}{cccc}
\hline No. & $\begin{array}{c}\text { Jumlah Tanggungan Keluarga } \\
\text { (orang) }\end{array}$ & Jumlah Petani (Jiwa) & Persentase (\%) \\
\hline 1. & 1 & - & - \\
2. & 2 & 2 & 5,0 \\
3. & 3 & 16 & 40,0 \\
4. & 4 & 18 & 45,0 \\
5. & 5 & 2 & 5,0 \\
6. & 6 & 2 & 5,0 \\
\hline & Jumlah: & 40 & 100 \\
\hline
\end{tabular}

Berdasarkan Tabel 7 dapat dilihat bahwa jumlah tanggungan terbesar yaitu jumlah tanggungan sebanyak 4 orang atau $45,0 \%$. Sedangkan jumlah tanggungan 2,5 , dan 6 sama-sama menduduki angka yang sama, yaitu tanggungan 2 orang atau $5 \%$. Responden yang mempunyai tanggungan 1 orang pada penelitian ini tidak ada.

\section{Volume Usaha}

Usaha ternak ayam broiler dan industri rumah tangga anyaman tikar purun yang dilaksanakan responden pada penelitian ini, mendapat suntikan dana yang bersumber dari BLM PUAP (Bantuan Langsung Masyarakat Program Pengembangan Usaha Agribisnis Perdesaan) tahun anggaran 2011. Dana PUAP yang dikucurkan Pemerintah Pusat melalui instansi terkait yang ada di Kabupaten Hulu Sungai Utara ini, besarnya Rp. 100.000.000,00 per tahun. Desa Panyaungan Kecamatan Amuntai Utara yang mendapatkan alokasi dana BLM PUAP tersebut, dimanfaatkan oleh anggota Gapoktan untuk usaha ternak ayam broiler (20 orang) dan usaha industri rumah tangga anyaman purun (20 orang). Masing-masing anggota mendapat bantuan pinjaman sebesar Rp.2.500.000,00.

Dana pinjaman sebesar itu oleh masing-masing anggota dipergunakan untuk menambah modal usaha. Bagi responden yang mengusahakan ternak ayam broiler, dana pinjaman tersebut dipergunakan untuk pengadaan bibit ayam, sedangkan bagi responden yang mengusahakan anyaman tikar purun, dana pinjaman tersebut dipergunakan untuk menambah dan atau pengadaan peralatan dan perlengkapan yang diperlukan untuk operasional usaha.

Banyaknya bibit ayam broiler yang diusahakan dan banyaknya tikar purun yang diusahakan oleh responden di Desa Panyaungan Kecamatan Amuntai Utara saat penelitian ini berlangsung dapat dilihat pada Tabel 8 dan Tabel 9.

Tabel 8. Banyaknya Ternak Ayam Broiler yang Diusahakan oleh Responden di Desa Panyaungan Kecamatan Amuntai Utara.

\begin{tabular}{cccc}
\hline No. & $\begin{array}{c}\text { Banyaknya } \\
\text { (ekor) }\end{array}$ & $\begin{array}{c}\text { Jumlah Petani } \\
\text { (orang) }\end{array}$ & Persentase $(\%)$ \\
\hline 1 & 600 ekor & 6 & 30 \\
2 & 700 ekor & 3 & 15 \\
3 & 800 ekor & 11 & 55 \\
4 & 900 ekor ke atas & - & - \\
\hline
\end{tabular}


Tabel 9. Rata-rata banyaknya tikar purun yang diusahakan oleh responden yang tergabung dalam pengrajin tikar purun di Desa Panyaungan Kecamatan Amuntai Utara.

\begin{tabular}{cccc}
\hline No. & Banyaknya (lembar) & $\begin{array}{c}\text { Jumlah Petani } \\
\text { (orang) }\end{array}$ & Persentase $(\%)$ \\
\hline 1 & 150 & 20 & 100 \\
\hline & Jumlah : & 20 & 100 \\
\hline
\end{tabular}

Berdasarkan Tabel 9 di atas terlihat bahwa responden yang mengusahakan tikar purun, rata-rata setiap orang bisa menyelesaikan tikar purun sebanyak 5 lembar per harinya, jadi selama satu bulan bisa memproduksi tikar purun se banyak 150 lembar.

\section{Analisis Biaya, Penerimaan dan Keuntungan}

\section{Biaya Tetap}

Pembiayaan usaha pemeliharaan ternak ayam broiler dan usaha anyaman tikar purun di tempat penelitian ini terdiri dari biaya tetap dan biaya variabel. Biaya tetap adalah biaya yang harus dikeluarkan, akan tetapi besar kecilnya biaya tidak dipengaruhi oleh besarnya produksi yang dicapai. Biaya tetap yang diperhitungkan dalam ke dua usaha pada penelitian ini terdiri dari biaya penyusutan alat dan perlengkapan, biaya tenaga kerja dalam keluarga (TKDK), dan biaya bunga modal.

\section{Biaya penyusutan.}

Biaya penyusutan pada ke dua usaha yang dilaksanakan oleh responden pada penelitian ini adalah berupa biaya penyusutan alat dan perlengkapan yang digunakan untuk kegiatan usaha tersebut. Biaya penyusutan diperhitungkan berdasarkan perkiraan umur pemakaian dari alat dan perlengkapan tersebut. Dalam memperkirakan umur pemakaian alat dan kelengkapan yang dipakai, antara alat yang satu dengan yang lainnya tidaklah sama, tergantung dari jenis peralatan dan perlengkapan yang dipakai.

Rata-rata besarnya biaya penyusutan alat dan perlengkapan yang digunakan dalam kegiatan usaha pemeliharaan ayam broiler dan anyaman tikar purun dapat dilihat pada Tabel 10 dan Tabel 11.

Tabel 10. Rata-rata besarnya biaya penyusutan alat dan perlengkapan yang digunakan untuk kegiatan usaha pemeliharaan ternak ayam broiler dalam satu periode pemeliharaan.

\begin{tabular}{clcc}
\hline No. & \multicolumn{1}{c}{ Jenis Alat dan Perlengkapan } & $\begin{array}{c}\text { Besarnya Biaya } \\
\text { Penyusutan (Rp.) }\end{array}$ & Persentase (\%) \\
\hline 1. & Kandang & $6.293,40$ & 69,87 \\
2. & Tempat Pakan & $1.006,94$ & 11,18 \\
3. & Tempat Minum & $1.678,24$ & 18,63 \\
4. & Sapu Lidi & 2,78 & 0,03 \\
5. & Ember & 26,04 & 0,29 \\
\hline & Jumlah : & $9.007,41$ & 100 \\
\hline
\end{tabular}

Tabel 11. Rata-rata besarnya biaya penyusutan alat dan perlengkapan yang digunakan untuk kegiatan usaha anyaman purun.

\begin{tabular}{clcc}
\hline No. & \multirow{2}{*}{ Jenis Alat dan Perlengkapan } & $\begin{array}{c}\text { Besarnya Biaya } \\
\text { Penyusutan (Rp.) }\end{array}$ & Persentase $(\%)$ \\
\hline 1. & Pisau & 10,42 & 1,03 \\
2. & Parang & 57,87 & 5,72 \\
3. & Tungku & 578,70 & 57,25 \\
4. & Drum & 16,67 & 1,65 \\
5. & Baskom & 347,22 & 34,35 \\
\hline & Jumlah : & $1.010,88$ & 100 \\
\hline
\end{tabular}


Dari Tabel 10 dan 11 di atas menunjukkan bahwa rata-rata besarnya biaya penyusutan terbesar adalah peralatan jenis kandang, yakni Rp. 6.293.40 atau 692,87\% dari usaha pemeliharaan ayam broiler, dan Rp. 578,70 atau $57,25 \%$ dari usaha anyaman tikar purun. Sedangkan biaya penyusutan terkecil berasal dari peralatan jenis sapu lidi, yakni Rp. 2,78 atau $0,03 \%$ per periode pemeliharaan, sedangkan untuk usaha anyaman tikar purun, biaya penyusutan terkecil adalah pada peralatan jenis pisau, yakni Rp.10,42 atau $1,03 \%$.

\section{Biaya Tenaga Kerja Dalam Keluarga (TKDK).}

Tenaga kerja dalam keluarga yang digunakan dalam kegiatan usaha pemeliharaan ternak ayam broiler maupun usaha anyaman tikar purun, di desa penelitian ini adalah tenaga kerja yang berasal dari dalam keluarga sendiri, terdiri dari tenaga kerja laki-laki dan tenaga kerja wanita. Ratarata penggunaan tenaga kerja dalam keluarga pada kedua jenis usaha tersebut dapat dilihat pada Tabel 12 dan Tabel 13.

Tabel 12. Rata-rata besarnya biaya Tenaga Kerja Dalam Keluarga (TKDK) yang digunakan untuk kegiatan usaha pemeliharaan ternak ayam broiler dalam satu periode pemeliharaan.

\begin{tabular}{|c|c|c|c|c|c|}
\hline \multirow[b]{2}{*}{ No. } & \multirow[b]{2}{*}{ Jenis Kegiatan } & \multicolumn{2}{|c|}{ Besarnya Biaya (Rp.) } & \multirow{2}{*}{$\begin{array}{c}\text { Jumlah } \\
\text { Biaya TKDK } \\
(\mathrm{Rp})\end{array}$} & \multirow[b]{2}{*}{$\%$} \\
\hline & & TKDK Pria & TKDK Wanita & & \\
\hline 1 & Pemberian pakan & $126.875,00$ & $126.875,00$ & $253.750,00$ & 46,98 \\
\hline 2 & Pemberian minum & $63.438,00$ & $63.438,00$ & $126.876,00$ & 23,49 \\
\hline 3 & Vaksinasi & $18.125,00$ & - & $18.125,00$ & 3,35 \\
\hline 4 & Pemberian vitamin/obat-obatan & $3.625,00$ & - & $3.625,00$ & 0,67 \\
\hline 5 & Pembersihan kandang & - & $36.250,00$ & $36.250,00$ & 6,71 \\
\hline \multirow[t]{2}{*}{6} & $\begin{array}{l}\text { Pembersihan tempat } \\
\text { pakan/Minum }\end{array}$ & - & $101.500,00$ & $101.500,00$ & 18,80 \\
\hline & Jumlah: & $212.630,00$ & $328.063,00$ & $540.125,00$ & 100,00 \\
\hline
\end{tabular}

Tabel 13. Rata-rata besarnya biaya Tenaga Kerja Dalam Keluarga (TKDK) yang digunakan untuk kegiatan usaha anyaman tikar purun.

\begin{tabular}{|c|c|c|c|c|c|}
\hline \multirow[b]{2}{*}{ No. } & \multirow[b]{2}{*}{ Jenis Kegiatan } & \multicolumn{2}{|c|}{ Besarnya Biaya (Rp.) } & \multirow[b]{2}{*}{$\begin{array}{c}\text { Jumlah Biaya } \\
\text { TKDK (Rp) }\end{array}$} & \multirow[b]{2}{*}{$\%$} \\
\hline & & $\begin{array}{c}\text { TKDK } \\
\text { Pria }\end{array}$ & TKDK Wanita & & \\
\hline 1 & Mencari purun & $150.000,00$ & - & $150.000,00$ & 18,18 \\
\hline 2 & Pembersihan kulit & $75.000,00$ & - & $75.000,00$ & 9,09 \\
\hline 3 & Penumbukan & $37.500,00$ & $37.500,00$ & $75.000,00$ & 9,09 \\
\hline 4 & Perebusan & - & $75.000,00$ & $75.000,00$ & 9,09 \\
\hline 5 & Pewarnaan \& penjemuran & - & $150.000,00$ & $150.000,00$ & 18,18 \\
\hline 6 & Penganyaman & - & $300.000,00$ & $300.000,00$ & 36,36 \\
\hline \multicolumn{2}{|c|}{ Jumlah: } & $262.500,00$ & $562.500,00$ & $825.000,00$ & 100,00 \\
\hline
\end{tabular}

Berdasarkan data di atas dapat dilihat bahwa ada pembagian pekerjaan antara pria dan wanita. Pada kegiatan usaha pemeliharaan ternak ayam broiler, pekerjaan yang memerlukan ketrampilan khusus, seperti vaksinasi, pemberian vitamin/obat-obatan, dikerjakan oleh pria, kegiatan yang sifatnya ringan dan tidak memerlukan ketrampilan khusus dikerjakan oleh wanita, seperti pembersihan kandang, dan pembersihan tempat pakan/minum.
Sedangkan pada usaha anyaman tikar purun, rata-rata kaum pria mengerjakan pekerjakan seperti mencari purun, pembersihan kulit dan menumbuk, bagi kaum wanitanya mengerjakan pekerjaan seperti perebusan, pewarnaan, penjemuran dan penganyaman.

Jenis kegiatan pada usaha pemeliharaan ternak ayam broiler yang biayanya paling besar adalah pekerjaan pemberian pakan, yakni Rp. 253.750,00 atau 
46,98\%. Dan untuk usaha anyaman tikar purun, yang terbanyak adalah pekerjaan penganyaman, yakni Rp. 300.000,00 atau 36,36. Sedangkan kegiatan yang biayanya paling kecil adalah pekerjaan vaksinasi, yaitu Rp. 3.625,00 atau 0,67\% untuk usaha pemeliharaan ayam broiler. Pada kegiatan usaha anyaman tikar purun, pekerjaan pembersihan kulit, penumbukan dan perebusan biayanya sama, yaitu Rp 75.000,00 atau $9,09 \%$ per bulan.

\section{Biaya Bunga Modal Sendiri.}

Biaya bunga modal dari usaha pemeliharaan ternak ayam broiler dan usaha anyaman tikar purun di desa penelitian ini, diperhitungkan berdasarkan tingkat suku bunga Bank yang berlaku. Dalam menentukan besarnya biaya bunga modal dalam usaha tersebut didasarkan pada besarnya biaya variabel dikalikan $0,5 \%$ dalam satu periode pemeliharaan/usaha. Rata-rata besarnya bunga modal sendiri yang dikeluarkan responden adalah $\mathrm{Rp}$. 28.612,19/periode (untuk usaha pemeliharaan ayam broiler). Adapun rata-rata biaya tetap yang dikeluarkan oleh responden pada usaha pemeliharaan ayam broiler dan usaha anyaman tikar purun, di desa Panyaungan Kecamatan Amuntai Utara dapat dilihat pada Tabel 14 dan Tabel 15.

Tabel 14. Rata-rata biaya tetap yang dikeluarkan responden yang mengusahakan ternak ayam broiler selama satu periode pemeliharaan.

\begin{tabular}{clrc}
\hline No. & \multicolumn{1}{c}{ Biaya Tetap } & Jumlah Biaya $(\mathrm{Rp})$. & Persentase $(\%)$ \\
\hline 1. & Biaya penyusutan alat & $9.007,41$ & 1,56 \\
2. & Biaya TKDK & $540.125,00$ & 93,48 \\
3. & Biaya Bunga Modal & $28.612,19$ & 4,96 \\
\hline & Jumlah : & $577.744,59$ & 100,00 \\
\hline
\end{tabular}

Tabel 15. Rata-rata biaya tetap yang dikeluarkan responden yang mengusahakan anyaman tikar purun selama satu bulan.

\begin{tabular}{clcc}
\hline No. & \multicolumn{1}{c}{ Biaya Tetap } & Jumlah Biaya (Rp.) & Persentase (\%) \\
\hline 1. & Biaya penyusutan alat & $1.010,88$ & 0,12 \\
2. & Biaya TKDK & $825.000,00$ & 99,64 \\
3. & Biaya Bunga Modal & $1.972,50$ & 0,24 \\
\hline & Jumlah : & $827.983,38$ & 100,00 \\
\hline
\end{tabular}

Berdasarkan Tabel di atas besarnya biaya tetap terbesar adalah Biaya Tenaga Kerja Dalam Keluarga (TKDK), yaitu sebesar Rp 540.125,00 atau 93,48\%(untuk responden yang mengusahakan pemeliharaan ayam broiler) dan Rp. 825.000,00 atau 99,64\% (untuk responden yang mengusahakan anyaman tikar purun). Sedangkan yang terkecil adalah biaya penyusutan alat, yaitu Rp. 9.007,41 atau 1,56\% untuk responden yang mengusahakan pemeliharaan ayam broiler, dan Rp. 1.010, 88 atau 0,12\% untuk responden yang mengusahakan anyaman tikar purun.

\section{Biaya Variabel}

Biaya variabel adalah biaya yang harus dikeluarkan pada suatu usaha yang besar kecilnya tergantung pada jumlah produksi yang dicapai. Biaya Variabel juga mempunyai hubungan yang erat dengan besar kecilnya atau tinggi rendahnya output yang dihasilkan. Komponen biaya variabel pada usaha pemeliharaan ternak ayam broiler terdiri dari: (1) biaya bahan (bibit ayam, biaya pakan, biaya vitamin, dan biaya obat-obatan); (2) biaya peralatan dan (3) biaya tenaga kerja luar keluarga (TKLK). Secara rinci perhitungan biaya variabel untuk kedua jenis usaha pada penelitian ini dapat dilihat pada Tabel 16 dan 17 berikut. 
Tabel 16. Rata-rata biaya variabel yang dikeluarkan responden yang mengusahakan ternak ayam broiler selama satu periode pemeliharaan.

\begin{tabular}{clcc}
\hline No. & \multicolumn{1}{c}{ Biaya Variable } & Jumlah Biaya (Rp.) & Persentase $(\%)$ \\
\hline 1. & Biaya Bahan: & $14.704 .750,00$ & 71,98 \\
& 1.1. Bibit ayam broiler & $2.900 .000,00$ & \\
& 1.2. Pakan & $11.418 .750,00$ & \\
& 1.3. Vitamin & $150.000,00$ & 28,02 \\
& 1.4. Obat-obatan & $236.000,00$ & - \\
2. & Biaya Peralatan \& Perlengkapan & $5.722 .438,00$ & 100,00 \\
\hline
\end{tabular}

Tabel 17. Rata-rata biaya variabel yang dikeluarkan responden yang mengusahakan anyaman tikar purun selama 1 bulan

\begin{tabular}{clcc}
\hline No. & \multicolumn{1}{c}{ Biaya Variable } & Jumlah Biaya (Rp.) & Persentase $(\%)$ \\
\hline 1. & Biaya Bahan: & $826.500,00$ & 67,69 \\
& 1.1. Purun & $750.000,00$ & \\
& 1.2. Pewarna & $9.000,00$ & \\
& 1.3. Kayu Bakar & $60.000,00$ & 32,31 \\
& 1.4. Tali Pengikat & $7.500,00$ & - \\
2. & Biaya Peralatan \& Perlengkapan & $394.500,00$ & 100,00 \\
\hline
\end{tabular}

Berdasarkan Tabel 16 dan 17 di atas terlihat bahwa biaya variabel terbesar yang dikeluarkan responden adalah pada biaya bahan, yaitu Rp. 14.704.7850,00 atau 71,98\% (untuk responden yang mengusahakan pemeliharaan ternak ayam broiler dan Rp.826.500,00 atau 67,69\% (untuk responden yang mengusahakan anyaman tikar purun). Sedangkan biaya variabel terkecil adalah biaya peralatan dan perlengkapan, yaitu sebesar Rp 5.722.437,00 atau 28,02\% (untuk responden yang mengusahakan pemeliharaan ayam broiler) dan Rp. 394.500,00 atau $32,31 \%$ (untuk responden yang mengusahakan anyaman tikar purun). Kedua jenis usaha yang dilaksanakan responden pada penelitian ini tidak menggunakan tenaga kerja luar keluarga, karena usaha tersebut hanyalah merupakan usaha sambilan disamping usaha pokoknya yaitu bercocok tanam padi.

\section{Produksi, Harga Jual dan Penerimaan}

Produksi dalam kegiatan usaha pemeliharaan ternak ayam broiler adalah berupa produksi daging. Dalam penelitian ini rata-rata responden memelihara ayam sebanyak 725 ekor. Dengan angka kematian rata-rata dalam satu periode mencapai $0,025 \%$ atau 18 ekor. Berarti dalam satu kali pemeliharaan jumlah ayam yang hidup ratarata 707 ekor dengan bobot rata-rata mencapai $1,9 \mathrm{~kg}$ per ekor. Dalam satu kali periode akan menghasilkan produksi daging sebanyak $1.331,85 \mathrm{~kg}$.

Harga jual dari produksi daging ayam broiler yang berlaku saat penelitian ini adalah Rp. $17.500,00$ per kg. Dengan demikian ratarata penerimaan dari usaha pemeliharaan ayam broiler selama periode tersebut mencapai Rp. 23.307.375,00. Adapun produksi dalam usaha anyaman tikar purun dalam penelitian ini adalah berupa tikar purun. Usaha kerajinan tikar purun ini hanya merupakan pekerjaan sambilan sambil menunggu musim panen padi tiba. Rata-rata responden dapat menyelesaikan 5 lembar tikar dalam sehari, berarti dalam satu bulan pengrajin dapat memproduksi tikar purun sebanyak 150 lembar. Untuk satu lembarnya dijual dengan harga Rp. 15.000,00. Artinya setiap responden akan menerima hasil usaha penjualan tikar purun sebanyak Rp. 2.250.000,00. Untuk jelasnya dapat dilihat pada Tabel 18 berikut.

Tabel 18. Rata-rata penerimaan yang diterima responden dari Desa Panyaungan 


\begin{tabular}{clccc}
\hline \multirow{2}{*}{ No. } & \multicolumn{1}{c}{ Jenis Produksi } & $\begin{array}{c}\text { Jumlah } \\
\text { Produksi }\end{array}$ & $\begin{array}{c}\text { Harga per satuan } \\
\text { (Rp.) }\end{array}$ & Jumlah Penerimaan (Rp.) \\
\hline 1. & Daging ayam broiler (kg) & $1.331,85$ & $17.500,00$ & $23.307 .375,00$ \\
2. & Tikar Purun (lembar) & 150 & $15.000,00$ & $2.250 .000,00$ \\
\hline
\end{tabular}

\section{Keuntungan}

Keuntungan adalah besarnya penerimaan dikurangi dengan biaya total. Keuntungan rata- rata dari responden Desa Panyaungan yang mengusahakan pemeliharaan ternak ayam broiler dan anyaman tikar purun dapat dilihat pada Tabel 19.

Tabel 19. Rata-rata keuntungan yang diperoleh responden dari usaha pemeliharaan ternak ayam broiler dan anyaman tikar purun.

\begin{tabular}{clccc}
\hline No. & \multicolumn{1}{c}{ Kegiatan } & $\begin{array}{c}\text { Penerimaan Rata- } \\
\text { rata (Rp.) }\end{array}$ & $\begin{array}{c}\text { Biaya Total Rata- } \\
\text { rata (Rp.) }\end{array}$ & $\begin{array}{c}\text { Keuntungan rata-rata } \\
\text { (Rp.) }\end{array}$ \\
\hline 1. & $\begin{array}{l}\text { Usaha Ternak Ayam } \\
\text { Broiler }\end{array}$ & $23.307 .375,00$ & $21.004 .324,00$ & $2.302 .443,00$ \\
& $\begin{array}{l}\text { Usaha Anyaman Tikar } \\
\text { Purun }\end{array}$ & $2.250 .000,00$ & $2.048 .983,00$ & $201.017,00$ \\
\hline
\end{tabular}

Berdasarkan data di atas terlihat bahwa responden yang mengusahakan pemeliharan ternak ayam broiler memperoleh keuntungan rata-rata sebesar $\mathrm{Rp}$. 2.302.443,00 per periode. Sedangkan responden yang mengusahakan anyaman tikar purun mendapatkan keuntungan sebesar Rp. $201.017,00$ per bulan. Kalau dilihat nilai keuntungannya memang tidak sebanding antara keuntungan yang diperoleh dari kedua usaha tersebut. Akan tetapi jika ditinjau dari biaya-biaya yang dikeluarkan untuk kedua usaha tersebut, nilainya juga sangat jauh berbeda.

\section{Kelayakan Usaha (Revenue Cost Ratio)}

Untuk mengetahui kelayakan usaha dari kedua jenis usaha yang dilakukan responden di Desa Panyaungan Kecamatan Amuntai Utara tersebut, yaitu dengan cara membandingkan antara penerimaan total suatu usahatani dengan biaya total yang dikeluarkan.

Besarnya Revenue Cost Ratio dari usaha pemeliharaan ayam broiler di desa tersebut dapat dilihat pada Tabel 20.

Tabel 20. Rata-rata besarnya RCR pada usaha pemeliharaan ternak ayam broiler dan anyaman tikar purun di Panyaungan.

\begin{tabular}{llccc}
\hline No. & \multicolumn{1}{c}{ Kegiatan } & $\begin{array}{c}\text { Rata-rata Penerimaan } \\
(\mathrm{Rp})\end{array}$ & $\begin{array}{c}\text { Biaya Total Rata-rata } \\
(\mathrm{Rp} .)\end{array}$ & Rata-rata RCR \\
\hline 1. & $\begin{array}{l}\text { Usaha Ternak Ayam } \\
\text { Broiler }\end{array}$ & $23.307 .375,00$ & $21.004 .324,00$ & 1,107 \\
2. & $\begin{array}{l}\text { Usaha Anyaman } \\
\text { Tikar Purun }\end{array}$ & $2.250 .000,00$ & $2.048 .983,00$ & 1,098 \\
\hline
\end{tabular}

Berdasarkan Tabel 20 di atas menunjukkan bahwa usaha pemeliharaan ternak ayam broiler di Desa Panyaungan Kecamatan Amuntai Utara rata-rata nilai RCR nya mencapai 1,107 , dan untuk usaha anyaman tikar purun rata-rata nilai RCR mencapai 1,098. Yang artinya setiap korbanan
Rp. 1,00 akan menghasilkan Rp. 1,107 untuk usaha ternak ayam broiler dan Rp. 1,098 untuk usaha anyaman tikar purun.
KESIMPULAN 
Biaya total untuk usaha ternak ayam broiler yang dilaksanakan responden di Desa Panyaungan Kecamatan Amuntai Utara Kabupaten Hulu Sungai Utara, rata-rata mencapai Rp. 21.004.932,10. Dengan rincian rata-rata biaya tetap sebesar Rp.577.744,60/periode pemeliharaan dan rata-rata biaya variabel mencapai Rp.20.427.187,50/periode pemeliharaan. Penerimaan rata-rata sebesar Rp.23.307.375,00/peroide pemeliharaan, dengan keuntungan rata-rata mencapai Rp.2.302443,00/periode pemeliharaan. Biaya total untuk usaha anyaman tikar purun yang dilaksanakan responden di Desa Panyaungan Kecamatan Amuntai Utara Kabupaten Hulu Sungai Utara, rata-rata mencapai Rp.2.048.983,40. Rata-rata biaya tetap yang dikeluarkan mencapai Rp.827.983,40/bulan, dan rata-rata biaya variabel yang dikeluarkan mencapai Rp.1.221.000,00/bulan. Penerimaan rata-rata mencapai Rp.2.250.000,00/ bulan, dan keuntungan ratarata yang diperoleh mencapai Rp. 201.017,00/bulan.

Berdasarkan data yang telah tersaji, usaha ternak ayam broiler dan anyaman tikar purun di desa penelitian tersebut, ternyata layak untuk diusahakan, karena nilai RCR dari kedua jenis usaha tersebut $>$ dari 1 . Nilai RCR pada usaha ternak ayam broiler mencapai 1,107 dan nilai RCR pada usaha anyaman purun mencapai 1,098. Dengan demikian usahatani yang diselenggarakan layak untuk diusahakan, karena setiap korbanan sebesar Rp. 1,00 akan menghasilkan Rp. 1,107 dan Rp. 1.098.

\section{DAFTAR PUSTAKA}

Boediono. 1979. Ekonomi Mikro. BPFE. Yogyakarta.

Darma, M. 2003. Penanggulangan kemiskinan dalam rangka pembangunan ekonomi daerah (studi penyaluran kredit dana bergulir bagi usaha kecil di Kota Balikpapan). Tesis Program Pasca Sarjana Universitas Brawijaya. Malang.
Arsyad, L. 2000. Ekonomi Manajerial. Edisi ke III. Cetakan 6. BPFE, Jakarta.

Wasis. 1981. Pengantar Ekonomi Mikro. Alumni. Bandung. 